$$
\begin{aligned}
& \frac{1}{k} 4^{-3} \\
& \text { Valdes, Alagka, 30th, } 1915 .
\end{aligned}
$$

Mr. IdTin Eokern,

Valdez, Ale gka.

Dear S1r:

On your request I have oxanlned a group of claima owned by Oherler $\mathrm{K}$. Notzlex of Valder, Alaska, and beg to subIt the following report.

\title{
LOOATIOR.
}

The Fotzler Group ooneleting of elx lode mineral ola1as, 1s eltuated on Mineral Greek, about I1ve m1les North of Valdez Bay.

\section{PHYSICAL REATUPES.}

The seotion of oountry traveraed by Minoral Creok 1. very mountalnous, rlaing abruptly from tho valloy to an olevation of approximately fivo thouand feet. Tho valley of Y1neral Oreek extending from Valdez Bay to the property everagea sbout one-half mile in width ilth a very 10r gradient. The elevation of y1neral creek at the property doos not exoeed two hundred feet above bea 10vel. Mineral creok furntabod oufflolont wator for milling requirements at the mine, and 11 eufflolent head oan be obtained farther up, this rater oould bo used for powor purposes. The Gevornment report statos that a fow hundred borae-porer oould be obtalned from the Eat fork of Minoral Orook.

\section{ACOI88ABILITY.}

A wagon road oxtende erom the beach to within a balf-a1le of the mino. The eotual oond1tion of this road 
In the cumber could not bo judged at the time of examination as the ground was oovered with enow. "During the winter monthe transportation rould be 1 deal.

There La a good shore-front for ahlpping at the mouth of Mineral Creek. A wharf whtoh was built there 18 partially destroyod and would nood ropalring if eny heavy freight ing ehould be done.

\section{GEOLOGI.}

The goology of the Mineral Orook sootion 1s sintlar to that gonerally found in the Prinoe Filliam sound Dietriot. The rooks oonel ot largely of slates and graywaokes. These sedimentary ser1ed otrike roughly Eagt host and dip at varying angles to the Horth. These rooks in wany plaoes have beon highly altered, forming sohists and other altered phoses of tho normal sodimentaries. This alteration 18 ahown on the Motzler property by the prosenos of a ride sone of orushod material, having an everage dip of about forty five degreee Horth.

\section{ORE SROTLIG.}

The ocouranoe of gold is very generel in the Yineral Oreak cootion whioh oontalne many properties of congidorablo pronlso. The gold oocure froe, and ageoolated rith pyrite, in quarta volna. Thosovroino aro generally omall and are in some asces reported to be vory rioh.

On the property in question the values are not conlinod to a narron quarta veln but oocur in a 20 one of orugbed slate. This zono is traveraed by a not-rork of narror quartz stringors making up from ton to trenty per cent of the ent1re 10de. The width of this sone on the suriace oould not be asoertained on account of snor, but it is sald by the owner that 1 averages forty feat and that it 
1. traoosble for sereral thousand feot. The undorgtgand rork tend to bear out the atatement of the owner regarding the 180 of the 10de, whioh statement 1e probebly true, but the value of this property will not depend alone upon the 120 of the mineral zone, but upon the amount of commerolal ore oontalned in the zone.

\section{IORR DONE.}

The ohlel rork done on the property conelste of tro tunnele driven on the lode from near the botton of uneral Oreok on elther s1de, where the oreek outs aoross the wineral sore. The tunnel on the Bagt side 18 about seventy1170 feet ling and that on the roet about one hundred and ton feet long. The omer olaimg that some ourtace worix hag been done to trace the oontinuation of the zone, but th1s oould not be seen.

The rook. In both tunnele oonsiats of orushed slate with many quarts etringers travereing it in various dircotiong. No ralls of a dofinite or limiting oharacter rore found in this rork, and it is probablo that no defin1to ralls exigt.

\section{VALURS.}

Ten samples rore tkken from the tunnols, fivo from esoh. These samples wore taken sorose the full width of the tunnel at 1ntervalo of p1fteen loet in Iunnel Number 1, and at interval of tronty feot in Tunnol Number 3 , Mth the exoeption of eamplo Futber 6, whloh wad takon along the tunnel from the ontranoe to the turn, as this part orosecut the zone of alneralization. The exaot position of eaoh of the following samples may be seon by referring to the acoompanying sketoh. 


\begin{tabular}{|c|c|c|}
\hline Sample & Gold, 080. & Value per ton. \\
\hline $\begin{array}{r}1 \\
2 \\
3 \\
4 \\
5 \\
6 \\
7 \\
8 \\
9 \\
10\end{array}$ & $\begin{array}{r}0.80 \\
0.36 \\
0.40 \\
0.10 \\
T r 800 \\
0.06 \\
0.08 \\
0.84 \\
0.62 \\
\text { Tra00 }\end{array}$ & $\begin{array}{r}\$ 16.00 \\
7.30 \\
8.00 \\
2.00 \\
\text { Tra0e } \\
1.30 \\
1.60 \\
16.80 \\
12.40 \\
\text { Treo0 }\end{array}$ \\
\hline
\end{tabular}

\section{OOFCLOSTOH.}

The IImited amount of 1nvostigation possible at the prosent time pointe to the faot that th1 property hos promise of beooming alno. If the average values of the alnerallsed gone prove to be equal to the average value of tho amples taken, I.E.,\$6.5a per ton, and if no rofractory olomente interfexenth the gold recovery in milling, the property +111 make a paying mine.

It in evident that the mall amount of work done osnnot in faimess be taken to represent the average of the 10de, so bofore any deflnite otatemente oan be made regarding olther velues, tonnage or ameneblitty to troatment of the ore present, a great deal more rork should be done and other investigatione mado.

There are no onglneering diffloulties to overoome in proviaing for trensportation or in preparing for tho mining and wllling operations. Before going to the oxpense of elaborate equipment tea thougand doliara, or filteon thousend dollars, should be intelligently spent in the further exploration of the property, and 15 this work prover tonnage and ralues oqual to those indlcated in the prosent rork, the property $\mathbf{m} 11$ be ono that can be freely reoomended as a profitable 1npestment.

Reopeotfully oubmitted, 